\title{
PERAN CONSUMER PERCEIVED VALUE DALAM ONLINE REVIEW TERHADAP IMPULSE BUYING TENDENCY MELALUI BROWSING SEBAGAI VARIABEL INTERVENING
}

\author{
Evi Mardian Ningsih \\ Universitas Negeri Surabaya \\ Evi.17080574038@mhs.unesa.ac.id \\ Anik Lestari Andjarwati \\ Universitas Negeri Surabaya \\ Aniklestari@unesa.ac.id
}

\begin{abstract}
Shopee is one of the favourable marketplaces in Indonesia. This research investigates impulse buying among Shopee user. In addition, it also analyzes the relationship between practical value, hedonic value, browsing, and impulse buying tendency. The survey was conducted using an online questionnaire and collected data from 211 respondents, the Shopee marketplace application users. Analysis of Structural Equation Modeling (SEM) in the Partial Least Square (PLS) program is used to analyze the data. The results show that the utilitarian value does not affect impulse buying tendency via browsing, and hedonic value affects impulse buying tendency via browsing. This research has limitations, which are: this research only involves the Shopee marketplace, so it is possible that it cannot be generalized to all types of marketplaces, and for further investigation, it can add or compare other marketplaces such as Tokopedia, Lazada, and Blibli. Supposedly, this study calls other variables, such as expressive value, sacrifice value, web quality, and purchase intention.
\end{abstract}

Keywords: browsing; e-commerce; hedonic value; impulse buying tendecy; utilitarian value.

\section{PENDAHULUAN}

Masa pandemi (Covid-19) mengharuskan masyarakat untuk beralih dari aktivitas offline ke online (Astyawan, 2020). Kondisi ini mengakibatkan penggunaan internet mengalami pergeseran yang sebelumnya hanya di kawasan perkotaan seperti kantor, kampus, sekolah dan tempat publik. Namun, saat ini bergeser ke perumahan, tempat tinggal dan pemukiman (Kominfo, 2020). Salah satu aktivitas yang mengalami peningkatan pada masa pandemi yaitu online shopping, yang meningkat sebesar 28,9\% (Santia, 2020). Selain itu juga, pandemi covid-19 menyebabkan jumlah transaksi jual beli di $e$ commerce mengalami peningkatan dua kali lipat yaitu sebesar 140 juta transaksi, dibandingkan dengan tahun sebelumnya hanya 80 juta transaksi (Uli, 2020).

Persaingan industri e-commerce nasional semakin lama semakin kompetitif. Bahkan, masing-masing platform e-commerce saling berlomba memberikan berbagai promo menarik serta inovasi yang memanjakan penggunanya di Indonesia (Deny, 2019). Kuartal 111 tahun 2020 persaingan platform marketplace di Indonesia menunjukkan Shopee meraih posisi teratas sebagai platform marketplace di Indonesia dengan jumlah pengunjung web bulanan tertinggi yaitu 96.532.300 pengunjung, Tokopedia di posisi ke-2 dengan jumlah 84.997.100 pengunjung dan Bukalapak di posisi ke-3. Selain itu, Shopee juga meraih posisi teratas sejak awal 2020 (Iprice, 2019).

Industri e-commerce di Indonesia telah memudahkan para konsumen dalam menikmati kemudahankemudahan ketika ingin belanja online. Konsumen harus memperhatikan hal sebelum berbelanja secara online terutama di marketplace yaitu melihat dan membaca ulasan produk dari konsumen lain baik berupa gambar, video, maupun rating (Tokopedia.com, 2020). Laporan tahunan WeAreSocial (2012), menyatakan bahwa terdapat $89 \%$ konsumen mencari informasi mengenai marketplace di internet dan online review sebagai pertimbangan untuk berbelanja. Kemudian, dari jumlah tersebut $80 \%$ konsumen akan mengurungkan niatnya untuk membeli ketika terdapat review buruk mengenai produk yang di inginkan Online review di artikan sebagai salah satu bentuk bagian dari User 
Evi Mardian Ningsih \& Anik Lestari Andjarwati. Peran Consumer Perceived Value dalam Online Review terhadap Impulse Buying Tendency melalui Browsing sebagai Variabel Intervening

Generated Content (UGC), selain itu postingan media sosial, teks, video blog, dan rating juga merupakan bagian dari User Generated Content (UGC) (Singh \& Chakrabarti, 2020)

UGC telah menarik perhatian terutama dalam bidang pemasaran. Pada penelitian sebelumnya, UGC terbukti memengaruhi keputusan pembelian (Adetunji et al., 2017). Sebelum membuat keputusan pembelian, banyak konsumen lebih suka memiliki akses ke online review untuk melihat pendapat dari konsumen lain tentang pengecer, produk, atau layanan online. Hal tersebut menunjukkan bahwa online review dapat memainkan peran penting dalam perilaku berbelanja (Zhang et al., 2014) dan online review juga dapat meningkatkan perilaku konsumen dalam menelusuri atau menjelajahi ulasanulasan dari konsumen lain (Zhang et al., 2018) dan juga perilaku browsing konsumen dapat memengaruhi impulse buying (Floh \& Madlberger, 2013).

Impulse buying dapat terjadi dalam konteks ulasan online. Misalnya, dengan menjelajahi marketplace konsumen dapat membayangkan kebutuhannya dan melakukan impulse buying serta tidak memiliki tujuan belanja khusus di awal (Zhang et al., 2018). Impulse buying didorong oleh objek yang menarik, yang menyebabkan konsumen melakukan pembelian tanpa mempertimbangkan konsekuensi finansial dan konsekuensi lain dari pembelian online (Sharma et al., 2010). Studi lain juga mengungkapkan bahwa perilaku impulse buying konsumen dipengaruhi secara positif oleh browsing (Zhang et al., 2018). Selain itu, Blazevic et al. (2013) mencatat bahwa karena perkembangan media sosial, pengaruh konsumen lain lebih masuk akal pada perilaku pembelian seseorang termasuk impulse buying. Menurut Chung \& Austria, (2012), sikap terhadap ulasan produk di media sosial dapat memengaruhi perilaku belanja impulsif meskipun konsumen tidak secara eksplisit membedakan apakah ulasan tersebut berasal dari pemasar atau konsumen lain. Dibandingkan dengan konsumen yang memiliki tujuan terarah, konsumen yang menjelajahi marketplace akan lebih cenderung membuat keputusan pembelian yang tidak direncanakan, karena mereka lebih mudah menerima pengaruh lingkungan (Moe, 2003).

Perilaku berbelanja pada awalnya dilakukan oleh konsumen secara rasional, yakni untuk mendapatkan manfaat yang diberikan. Namun, saat ini berbelanja juga dipengaruhi oleh nilai yang bersifat emosional yakni untuk merasakan kenikmatan dan kesenangan. Shopping bukan hanya sebuah kegiatan untuk memenuhi kebutuhan hidup saja, tetapi juga telah menjadi sebuah gaya hidup. Pada kondisi saat ini shopping menjadi hobi dan kesenangan tersendiri. Banyak orang membeli produk walaupun mereka tidak memerlukan produk tersebut, tetapi tidak jarang konsumen melakukan browsing dan mengunjungi berbagai laman toko hanya untuk membeli kebutuhannya. Nilai yang dirasakan konsumen atau consumer perceived value terbukti penting dalam memfasilitasi dan memprediksi perilaku konsumen (Overby \& Lee, 2006). Zhang et al. (2018) mengungkapkan bahwa utilitarian value dan hedonic value yang dirasakan oleh konsumen dari membaca online review dapat meningkatan browsing mereka.

Tingkatan impulsif konsumen akan sangat memengaruhi perilaku konsumen untuk menjelajahi dan akhirnya melakukan impulse buying. Namun, konsumen dengan tingkat impulsif tinggi, akan lebih menitik beratkan pada hedonic value dalam ulasan online untuk melakukan browsing. Begitu pula sebaliknya, konsumen dengan tingkat impulsif rendah justru menunjukkan hasil yang tidak signifikan terhadap browsing. Selain itu, belum banyak penelitian empiris mengenai online review dan impulse buying. Penelitian mengenai impulse buying akan membantu pemasar di marketplace untuk memahami perilaku konsumen dalam mereview produk dan melakukan pembelian tidak terencana (Zhang et al., 2018).

Berdasarkan fenomena di atas, penelitian ini bertujuan untuk menguji secara empiris pengaruh variabel consumer perceived value yaitu utilitarian value dan hedonic value dalam online review terhadap variabel impulse buying tendency melalui browsing sebagai variabel intervening pada pengguna marketplace Shopee. 


\section{KAJIAN PUSTAKA DAN PENGEMBANGAN HIPOTESIS}

\section{Consumer Perceived Value}

Menurut Woodruff (1997), nilai konsumen merupakan konsep penting dalam literatur pemasaran yang mengacu tentang apa yang diinginkan dan dipercaya konsumen selama berbelanja atau menikmati layanan. Ketika membaca online review, konsumen akan lebih mendapatkan utilitarian value dan hedonic value dari pada nilai lainnya. Menurut Smith \& Colgate (2007), terdapat empat macam perceived value yaitu symbolic/expressive value, cost/sacrifice value, utilitarian value, dan hedonic value.

\section{Utilitarian Value}

Kim \& Eastin (2011) mendefinisikan utilitarian value sebagai nilai lebih konsumen yang memiliki sifat kognitif yaitu nilai yang terkait dengan kegunaan. Utilitarian value diartikan sebagai persepsi konsumen tentang sejauh mana online review dapat memberikan nilai instrumental dan memenuhi kebutuhan mereka (Zhang et al., 2018). Indikator utilitarian value menurut Kim (2006) yaitu sebagai berikut. (1) Achievement: orientasi belanja di mana keberhasilan dalam menemukan produk atau jasa tertentu yang direncanakan pada awal perjalanan berbelanja dan hal tersebut dianggap penting; (2) Efficiency: kebutuhan konsumen untuk menghemat waktu dan sumber daya.

\section{Hedonic Value}

Menurut Zhang et al. (2018), hedonic value merupakan persepsi konsumen tentang sejauh mana ulasan online dapat memberikan nilai dan kesenangan yang terpenuhi dengan sendirinya. Menurut Kim \& Eastin (2011), hedonic value sebagai nilai konsumen yang memiliki sifat afektif atau nilai yang terkait dengan emosi. Indikator hedonic value menurut Holbrook, \& Hirschman (1982), yaitu sebagai berikut. (1) Enjoyment: perilaku konsumen yang berkaitan dengan kenikmatan sebagai tujuan hidup; (2) Fantasy: perilaku konsumen yang berhubungan dengan khayalan atau dengan hanya ada dalam benak atau pikiran saja dan atau ketidaksadaran.

\section{Perilaku Pencarian Informasi (Information Seeking Behavior)}

Menurut Wilson (1999), perilaku pencarian informasi merupakan suatu perilaku mikro yang digunakan untuk berinteraksi dengan sistem informasi. Interaksi tersebut berupa interaksi langsung antara pencari informasi dengan sistem informasi. Misalnya, tindakan pengguna saat mengaplikasikan mouse (perangkat keras pada komputer) yang di mana mereka melakukan pencarian informasi dengan cara meng-klik sebuah tautan. Menurut Ellis (1993), model perilaku pencarian infomasi dianggap sebagai beberapa perilaku yang terlibat dalam pencarian informasi yang tidak ditetapkan dalam model diagram dan terdapat fitur-fitur yang digunakan dalam model perilaku pencarian informasi. Enam fitur dalam model pencarian informasi yaitu sebagai berikut. (1) Starting: cara yang digunakan oleh pencari/pengguna informasi untuk memulai mencari informasi. Misalnya, mengajukan beberapa pertanyaan kepada rekan atau orang-orang yang memiliki pengetahuan; (2) Chaining: mengikuti footnotes dan kutipan dalam materi yang telah diketahui atau rangkaian "forward" dari item yang diketahui melalui indeks kutipan; (3) Browsing: pencarian semi-terarah atau semi-terstruktur di area yang berpotensi untuk menarik pencari atau pengguna; (4) Differentiating: pemilahan yang menggunakan ciri-ciri di dalam sumber informasi sebagai acuan dasar untuk memeriksa kualitas atau isi informasi; (5) Monitoring: memantau perkembangan dengan berfokus pada beberapa sumber informasi yang terpilih; dan (6) Extracting: menggali satu sumber informasi secara sistematis untuk mengambil informasi yang dianggap penting.

\section{Browsing}

Browsing merupakan perilaku yang dilakukan dalam bentuk penyaringan informasi, mulai dari window-shopping hingga pengumpulan informasi (Xia, 2010). Bloch et al. (1989) mengemukakan browsing sebagai aktivitas pencarian yang berkelanjutan tanpa menyusun perencanaan pembelian khusus. Menurut Ellis (1993), browsing merupakan proses pencarian semi-terarah atau semiterstruktur di area yang berpotensi untuk menarik perhatian pencari atau pengguna informasi. Indikator browsing oleh Floh \& Madlberger (2013) sebagai berikut. (1) Enthusiastic: perasaan positif 
Evi Mardian Ningsih \& Anik Lestari Andjarwati. Peran Consumer Perceived Value dalam Online Review terhadap Impulse Buying Tendency melalui Browsing sebagai Variabel Intervening

yang mencerminkan sejauhmana seseorang merasa aktif; (2) Serenity: sejauhmana seseorang merasa nyaman dan tenang.

\section{Impulse Buying}

Menurut Piron (1991), impulse buying dianggap sebagai pembelian yang tidak direncanakan, hasil paparan dari proses belanja atau stimulus tertentu dan keputusan langsung yang diputuskan saat itu juga. Impulse buying adalah keputusan untuk membeli produk atau jasa yang dilakukan secara tidak disengaja (Lim et al., 2017). Sedangkan menurut Bayley \& Nancarrow (1998), impulse buying merupakan perilaku konsumen yang terjadi secara tiba-tiba, bersifat menarik, dan kompleks secara hedonis di mana konsumen tidak menyadari tentang informasi dan pilihan alternatif. Rook (1987) menjelaskan impulse buying terjadi ketika pelanggan mengalami dorongan secara tiba-tiba dan terusmenerus untuk segera membeli produk atau jasa. Indikator impulse buying menurut Lee \& Kacen (2002) sebagai berikut. (1) Spontaneous: pembelian impusif yang terjadi secara tidak terduga dan memotivasi konsumen untuk membeli pada saat itu juga; (2) Passion: keinginan membeli secara tibatiba yang seringkali diikuti oleh emosi seperti exciting, thrilling, atau wild; (3) Compulsive strength: adanya motivasi untuk mengesampingkan hal-hal lain dan bertindak secepatnya; dan (4) Indifference: keinginan untuk membeli dapat menjadi tidak dapat ditolak atau konsumen hanya tertarik untuk membeli saja walaupun belum mengetahui akibat yang mungkin akan ditimbulkan saat memutuskan untuk membeli produk tersebut.

\section{Hubungan antar Variabel}

Menurut Zhang et al. (2018), dilihat dari perspektif nilai konsumen, ketika konsumen membaca online review konsumen akan mendapatkan utilitarian value. Jika konsumen mendapatkan utilitarian value dari pencarian secara online, maka akan terbentuk niat konsumen untuk mencari. Jika konsumen merasa bahwa mereka dapat memperoleh informasi yang berguna dari ulasan online, mereka akan menjelajahinya. Wang (2010) membuktikan bahwa utilitarian value dari pencarian informasi memiliki hubungan positif dengan konsumen. Secara keseluruhan, utilitarian value menghasilkan nilai yang signifikan terhadap browsing. Namun, utilitarian value memiliki hasil yang tidak signifikan terhadap browsing ketika konsumen dengan tingkat impulsif tinggi. Sebaliknya, jika konsumen dengan tingkat impulsif rendah, utilitarian value menunjukkan hasil yang signifikan terhadap browsing (Zhang et al., 2018). Wahab et al. (2018) dan Mikalef et al. (2012) telah membuktikan bahwa utilitarian value memiliki pengaruh langsung terhadap browsing.

H1: Terdapat pengaruh positif utilitarian value terhadap browsing pada pengguna Marketplace Shopee.

Menurut Zhang et al. (2018), hedonic value memainkan peran penting dalam mendorong konsumen untuk menjelajahi dan perilaku impulse buying. Konsumen cenderung akan menjelajahi, ketika merasa senang (Pöyry et al., 2013). Kesenangan dan kenikmatan yang diterima konsumen dari ulasan online akan lebih cenderung menghabiskan waktu mereka untuk menjelajahi ulasan online dan telah membuktikan bahwa hedonic value menunjukkan hasil yang signifikan terhadap browsing. Namun, pada konsumen yang memiliki tingkat impulsif rendah menunjukkan hasil yang tidak signifikan antara hedonic value terhadap browsing. Sehingga, konsumen dengan impulsif tinggi lebih menitikberatkan pada hedonic value ulasan online untuk melakukan browsing (Zhang et al., 2018). Sedangkan, penelitian Gultekin \& Ozer (2012) dan Wahab et al. (2018) menunjukkan hasil yang signifikan antara hedonic value terhadap perilaku browsing.

H2: Terdapat pengaruh positif hedonic value terhadap browsing pada pengguna Marketplace Shopee.

Menurut Floh \& Madlberger (2013), utilitarian value dapat memicu prilaku impulse buying artinya semakin tinggi tingkat impulsif konteks spesifik konsumen, semakin banyak produk yang akan mereka beli secara impulsif. Dengan kata lain, nilai kegunaan seperti kualitas produk yang baik dengan harga murah, yang disimulasikan oleh e-commere dapat memicu perilaku pembelian yang impulsif dan hasil membuktikan bahwa utilitarian value memiliki pengaruh positif yang kuat terhadap 
perilaku impulse buying secara elektronik (Lim et al., 2017). Utilitarian value berhubungan positif dengan impulse buying (Wang, 2017).

H3: Terdapat pengaruh positif utilitarian value terhadap impulse buying tendency pada pengguna marketplace Shopee.

Menurut Floh \& Madlberger (2013), hedonic value juga dapat memicu perilaku pembelian konsumen secara impulsif artinya semakin tinggi tingkat impulsif situasional konsumen, semakin banyak produk yang akan mereka beli secara impulsif. Dengan kata lain, nilai-nilai yang dipersepsikan seperti hedonic value misalnya, kesenangan pada saat berbelanja di e-commere dapat memicu perilaku pembelian yang impulsif dan membuktikan bahwa hedonic value memiliki pengaruh yang lebih kuat dibandingkan dengan utilitarian value terhadap perilaku konsumen untuk membeli secara impulsif melalui elektronik (Lim et al., 2017). Hedonic value terbukti memiliki pengaruh yang signifikan terhadap pembelian produk secara impulsif (Gultekin \& Ozer, 2012; Wahab et al., 2018; Wang, 2017).

H4: Terdapat pengaruh positif hedonic value terhadap impulse buying tendency pada pengguna marketplace Shopee.

Browsing dianggap sebagai perilaku non-pembelian dalam pembelian produk, dan juga dianggap sebagai aktivitas untuk bersenang-senang, mengisi waktu menunggu, atau mengumpulkan informasi produk (Yi \& Jai, 2020). Contohnya, keragaman produk secara signifikan memengaruhi perilaku browsing konsumen dengan utilitarian value. Hal tersebut akan menghambat perilaku impulse buying. Di sisi lain, harga memainkan peran penting dalam meningkatkan perilaku browsing yang memiliki efek positif pada perilaku impulse buying konsumen (Park et al., 2012). Studi sebelumnya dalam penelitian Floh \& Madlberger (2013) membuktikan bahwa browsing memiliki hasil yang signifikan terhadap impulse buying. Selain itu, Gultekin \& Ozer (2012); Wahab et al. (2018) telah membuktikan bahwa browsing memengaruhi impulse buying .

H5: Terdapat pengaruh positif browsing terhadap impulse buying tendency pada pengguna marketplace Shopee.

Utilitarian value yang kuat pada konsumen akan melakukan browsing produk sebagai langkah awal untuk mencari informasi tentang produk (Chung et al., 2017). Semakin sering konsumen mempertimbangkan nilai fungsional dari situs belanja online, semakin besar keinginan mereka untuk melakukan impulse buying dalam lingkungan belanja online (Ha \& Jang, 2010). Penelitian yang dilakukan oleh Chen et al. (2019) terhadap impulse buying di situs e-commerce menunjukkan bahwa browsing memediasi pengaruh antara utilitian value dan hedonic value terhadap impulse buying. Perilaku browsing telah diidentifikasi bahwa hubungan antara hedonic value dan impulse buying mampu dimediasi oleh browsing (Gultekin \& Ozer, 2012). Konsumen akan terdorong untuk mengeksplorasi atau mencari informasi produk lebih lama dan menikmati proses browsing sebagai kesenangan dalam memenuhi hasrat mereka yang selanjutnya dapat meningkatkan impulse buying (Erkip, 2005). Penelitian oleh Wahab et al. (2018) pada wanita yang telah melakukan pembelian produk fashion di Social Commerce yaitu Instagram menunjukkan hasil bahwa browsing mampu memediasi hubungan antara utilitarian value dan hedonic value pada impulse buying.

H6: Terdapat pengaruh positif utilitarian value terhadap impulse buying tendency melalui browsing pada pengguna marketplace Shopee.

H7: Terdapat pengaruh positif hedonic value terhadap impulse buying tendency melalui browsing pada pengguna marketplace Shopee. 
Evi Mardian Ningsih \& Anik Lestari Andjarwati. Peran Consumer Perceived Value dalam Online Review terhadap Impulse Buying Tendency melalui Browsing sebagai Variabel Intervening

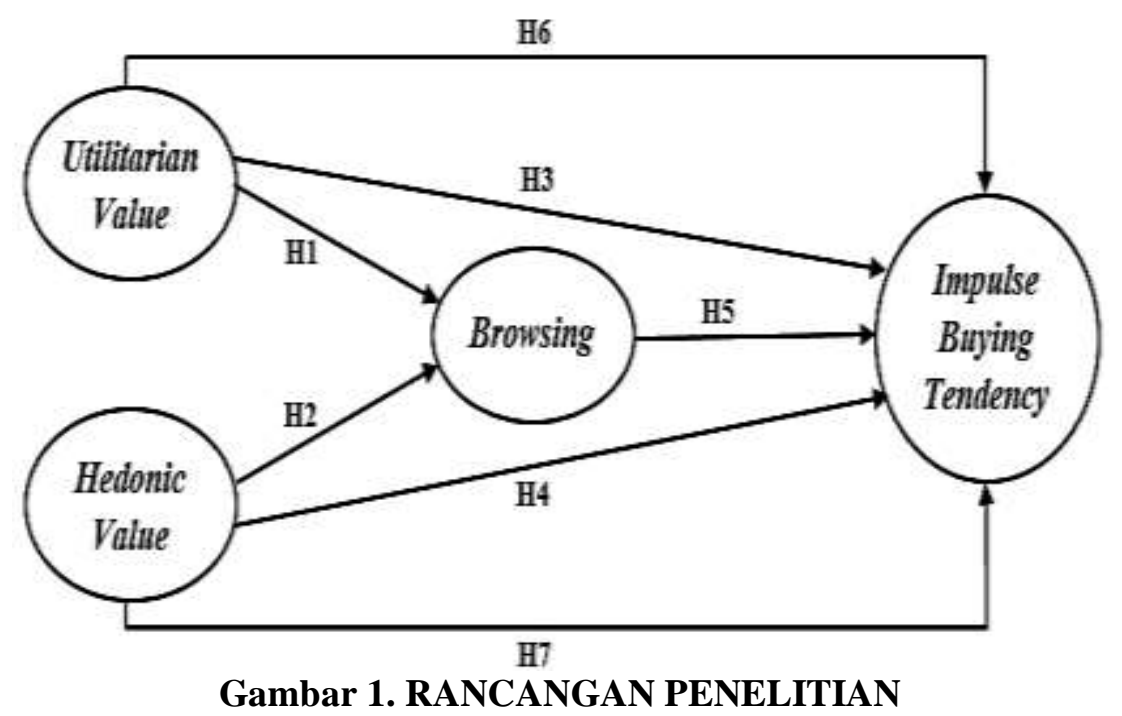

Gambar 1 merupakan model penelitian yang menunjukkan hubungan antar variabel diantaranya variabel independent yaitu utilitarian value (X1) dan hedonic value (X2), kemudian variabel dependent yaitu impulse buying tendecy $(\mathrm{Y})$, serta browsing $(\mathrm{Z})$ sebagai variabel intervening atau mediasi.

\section{METODE PENELITIAN}

Pada penelitian ini, rancangan penelitian yang digunakan adalah konklusif. Analisis data yang digunakan yaitu kuantitatif. Populasi penelitian ini yaitu pelanggan marketplace Shopee. Teknik sampling dalam penelitian ini menggunakan nonprobability sampling. Metode pengambilan sampel yang digunakan ialah judgemental sampling untuk memilih elemen yang sesuai dengan karakteristik responden dari populasi yang diteliti (Malhotra, 2009:361). Karakteristik responden ini yaitu memiliki usia minimal 15 tahun yang merupakan pengguna marketplace Shopee dan pembeli online yang telah melakukan pembelian di marketplace Shopee minimal 1 bulan sekali.

Sampel pada penelitian ini berjumlah 211 responden. Angket dibuat dengan menggunakan google form berupa pertanyaan tertutup dengan skala Likert 1-5 dengan kategori sangat tidak setuju hingga sangat setuju (Malhotra, 2009:298). Selain itu, angket juga berisi pertanyaan untuk mengetahui profil responden diantaranya adalah mengenai jenis produk yang sering dibeli di marketplace Shopee, perangkat komunikasi yang digunakan, lama penggunaan marketplace Shopee, tingkat kunjungan ke marketplace Shopee yang artinya sudah berapa lama responden menggunakan dan mengunjungi tersebut, serta marketplace lain yang dimiliki kecuali marketplace Shopee. Data didapat dengan cara menyebarkan link angket secara online yaitu melalui Instagram, Facebook, Line, Telegram, dan Whatsapp. Teknik analisis data yaitu Structural Equation Modeling (SEM) dengan menggunakan program Partial Least Square (PLS).

Tabel 1 menyajikan butir-butir pernyataan pada angket online. Pernyataan-pernyataan tersebut telah di validasi oleh ahli di bidang pemasaran dan di uji validitas serta reliabilitasnya menggunakan perhitungan nilai convergent validity $(\mathrm{CV})$ dan cronbach's alpha (CA) melalui software SmartPLS 


\section{Tabel 1. \\ BUTIR PERNYATAAN ANGKET}

\begin{tabular}{|c|c|c|}
\hline Variabel & Butir Pernyataan Angket & Sumber \\
\hline $\begin{array}{c}\text { Utilitarian } \\
\text { Value }\end{array}$ & $\begin{array}{l}\text { Saya merasa ketersediaan penilaian yang mendetail tentang produk di } \\
\text { marketplace Shopee adalah hal yang penting bagi saya. } \\
\text { Saya merasa bahwa membaca penilaian produk di marketplace Shopee } \\
\text { bermanfaat bagi saya. } \\
\text { Saya merasa puas ketika membaca penilaian produk di marketplace Shopee. } \\
\text { Saya menemukan Informasi yang saya cari dengan membaca penilaian produk } \\
\text { di marketplace Shopee. } \\
\text { Saya dapat mencari informasi tentang produk dengan cepat dengan membaca } \\
\text { penilaian produk di marketplace Shopee. } \\
\text { Saya dapat membandingkan informasi tentang produk dengan cepat dengan } \\
\text { membaca penilaian produk di marketplace Shopee. } \\
\text { Saya membaca penilaian produk di marketplace Shopee untuk bisa mendapatkan } \\
\text { respon lebih cepat dari penjual. } \\
\text { Saya membaca penilaian produk di marketplace Shopee untuk dapat berbelanja } \\
\text { secara efisien. }\end{array}$ & $\begin{array}{l}\text { Adaptasi dari } \\
\text { Hazari et al. } \\
\text { (2017); Wang, } \\
\text { (2010); Kim, } \\
\text { (2006) }\end{array}$ \\
\hline $\begin{array}{c}\text { Hedonic } \\
\text { Value }\end{array}$ & $\begin{array}{l}\text { Saya merasa senang ketika mencari informasi dengan membaca penilaian } \\
\text { produk di marketplace Shopee. } \\
\text { Saya merasa mencari informasi dengan membaca penilaian produk di } \\
\text { marketplace Shopee tidak membosankan. } \\
\text { Saya merasa nyaman ketika membaca penilaian produk di marketplace Shopee. } \\
\text { Saya menikmati membaca penilaian produk di marketplace Shopee. } \\
\text { Saya merasa mencari informasi dengan membaca penilaian produk di } \\
\text { marketplace Shopee adalah cara yang terbaik untuk menghabiskan waktu. } \\
\text { Saya dapat melupakan kesedihan saya ketika membaca penilaian produk di } \\
\text { marketplace Shopee. } \\
\text { Saya dapat merasakan apa yang dirasakan konsumen lain yang telah membeli } \\
\text { produk dengan membaca penilaian produk tersebut di marketplace Shopee. }\end{array}$ & $\begin{array}{l}\text { Adaptasi dari } \\
\text { Hazari et al. } \\
\text { (2017); Wang, } \\
\text { (2010); Lee \& } \\
\text { Wu, (2017) }\end{array}$ \\
\hline Browsing & $\begin{array}{l}\text { Saya menjelajahi marketplace Shopee untuk mendapatkan respon lebih cepat } \\
\text { dari penjual. } \\
\text { Saya menghabiskan banyak waktu hanya untuk menjelajahi marketplace } \\
\text { Shopee. } \\
\text { Saya merasa senang ketika menjelajahi marketplace Shopee. } \\
\text { Saya dapat melupakan masalah saya ketika menjelajahi marketplace Shopee. } \\
\text { Saya menikmati menjelajahi marketplace Shopee. } \\
\text { Saya merasa nyaman ketika menjelajahi marketplace Shopee. }\end{array}$ & $\begin{array}{l}\text { Adaptasi dari } \\
\text { Beatty \& } \\
\text { Elizabeth } \\
\text { Ferrell, } \\
\text { (1998); Park et } \\
\text { al. (2012) }\end{array}$ \\
\hline $\begin{array}{c}\text { Impule } \\
\text { Buying } \\
\text { Tendency }\end{array}$ & $\begin{array}{l}\text { Saya berkeinginan untuk membeli produk sebagai tambahan tujuan belanja saya } \\
\text { di marketplace Shopee. } \\
\text { Saya membeli produk yang tidak direncanakan di marketplace Shopee. } \\
\text { Saya tidak berniat untuk membeli sebelum mengunjungi marketplace Shopee. } \\
\text { Saya tidak ragu untuk membeli produk di marketplace Shopee dengan segera } \\
\text { setelah melihat produk yang saya inginkan. } \\
\text { Saya tidak sadar ketika membeli produk di marketplace Shopee. } \\
\text { Saya berkeinginan untuk membeli produk yang tidak ada hubungannya dengan } \\
\text { tujuan belanja saya di marketplace Shopee. } \\
\text { Saya melupakan tujuan awal belanja saya setelah melihat produk di marketplace } \\
\text { Shopee. } \\
\text { Saya akan segera membeli produk di marketplace Shopee tanpa memperhatikan } \\
\text { kegunaannya untuk saya. } \\
\text { Saya tidak dapat menolak untuk membeli produk di marketplace Shopee. }\end{array}$ & $\begin{array}{l}\text { Adaptasi dari } \\
\text { Lim } \text { et al. } \\
\text { (2017); } \\
\text { Parboteeah } \text { et } \\
\text { al. }(2009) ; \\
\text { Verhagen \& } \\
\text { Van Dolen, } \\
\text { (2011) }\end{array}$ \\
\hline
\end{tabular}

\section{HASIL DAN PEMBAHASAN}

\section{Karakteristik Responden}

Responden merupakan pengguna marketplace Shopee yang pernah melakukan pembelian dalam 
Evi Mardian Ningsih \& Anik Lestari Andjarwati. Peran Consumer Perceived Value dalam Online Review terhadap Impulse Buying Tendency melalui Browsing sebagai Variabel Intervening

kurun waktu setiap hari sebanyak 6 orang (3\%), 2-3 kali dalam seminggu sebanyak 17 orang (8\%), seminggu sekali sebanyak 23 orang (11\%), 2-3 kali dalam sebulan sebanyak 106 orang (50\%) dan sebulan sekali sebanyak 59 orang (28\%). Selanjutnya responden dengan usia 15-20 tahun sebanyak 63 orang (30\%), 21-25 tahun sebanyak 134 orang (64\%), 26-30 tahun sebanyak 7 orang (3\%), dan >30 tahun sebanyak 7 orang $(3 \%)$. Responden berjenis kelamin perempuan sebanyak $85 \%$, sisanya berjenis kelamin laki-laki. Jenis pekerjaan pada responden didominasi oleh siswa/mahasiswa sebanyak $81 \%$ sisanya seperti ibu rumah tangga, karyawan swasta, pegawai negeri, pegawai kependidikan, dan wirausaha. Kenudian, responden dengan pengeluaran perbulan untuk belanja online sebanyak <Rp.500.000 (72\%), Rp.500.000-999.999 (20\%), Rp.1.000.000-1.499.999 (6\%) dan Rp.1.500.000-2.000.000 (1\%). Selain itu, untuk mengetahui lebih lanjut mengenai profil dari responden telah disajikan pada Gambar 2.

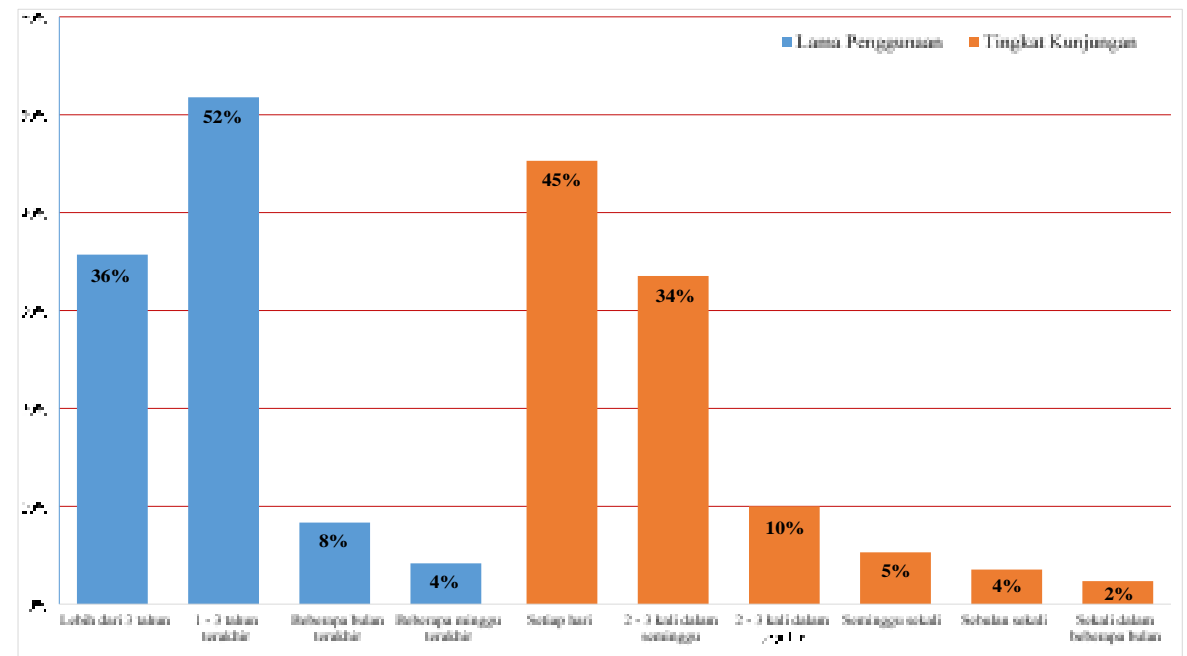

Sumber: Data diolah

\section{Gambar 2. LAMA PENGGUNAAN DAN TINGKAT KUNJUNGAN}

Gambar 2 memperlihatkan tingkat presentase lama penggunaan dan tingkat kunjungan pada marketplace Shopee artinya bahwa konsumen yang menggunakan marketplace Shopee paling lama 13 tahun terakhir dan dalam tingkat pengunjungannya konsumen mengunjungi marketplace Shopee setiap hari. Hal tersebut menunjukkan bahwa konsumen aktif berinteraksi di dalam marketplace Shopee. Selain itu, alat/perangkat komunikasi yang paling banyak digunakan untuk berinteraksi di dalam marketplace Shopee adalah smartphone yaitu sebesar 87\%, itu artinya konsumen merasa lebih fleksibel dan lebih santai karena konsumen dapat melakukan browsing dan pembelian dengan sangat mudah, kapanpun dan di manapun. Bahkan dengan bertransaksi pun sudah dapat dilakukan melalui smartphone.

Selanjutnya, jenis produk yang sering dibeli konsumen yaitu fashion (25\%) dan kecantikan (18\%) karena perempuan lebih dominan jadi wajar jikalau jenis produk fashion dan kecantikanlah yang menjadi langganan pada saat berbelanja online di marketplace Shopee. Kemudian, selain marketplace Shopee terdapat marketplace lainnya yang menjadi favorit konsumen yaitu Tokopedia (36\%) dan disusul dengan Lazada sebesar (24\%). Sehingga, marketplace Shopee dan Tokopedia merupakan marketplace yang paling disukai banyak orang.

\section{Convergent Validity}

Hasil uji kevaliditasan dari keseluruhan indikator, terlihat bahwa semua bernilai di atas standar minimal validity yang telah ditetapkan yaitu 0,50 sehingga demikian dapat dikatakan valid (Ghozali, 2016). Convergent Validity dapat dilihat pada nilai garis hubungan antara variabel dengan item pernyataan. Hasil lebih detail dapat dilihat di Gambar 3. 


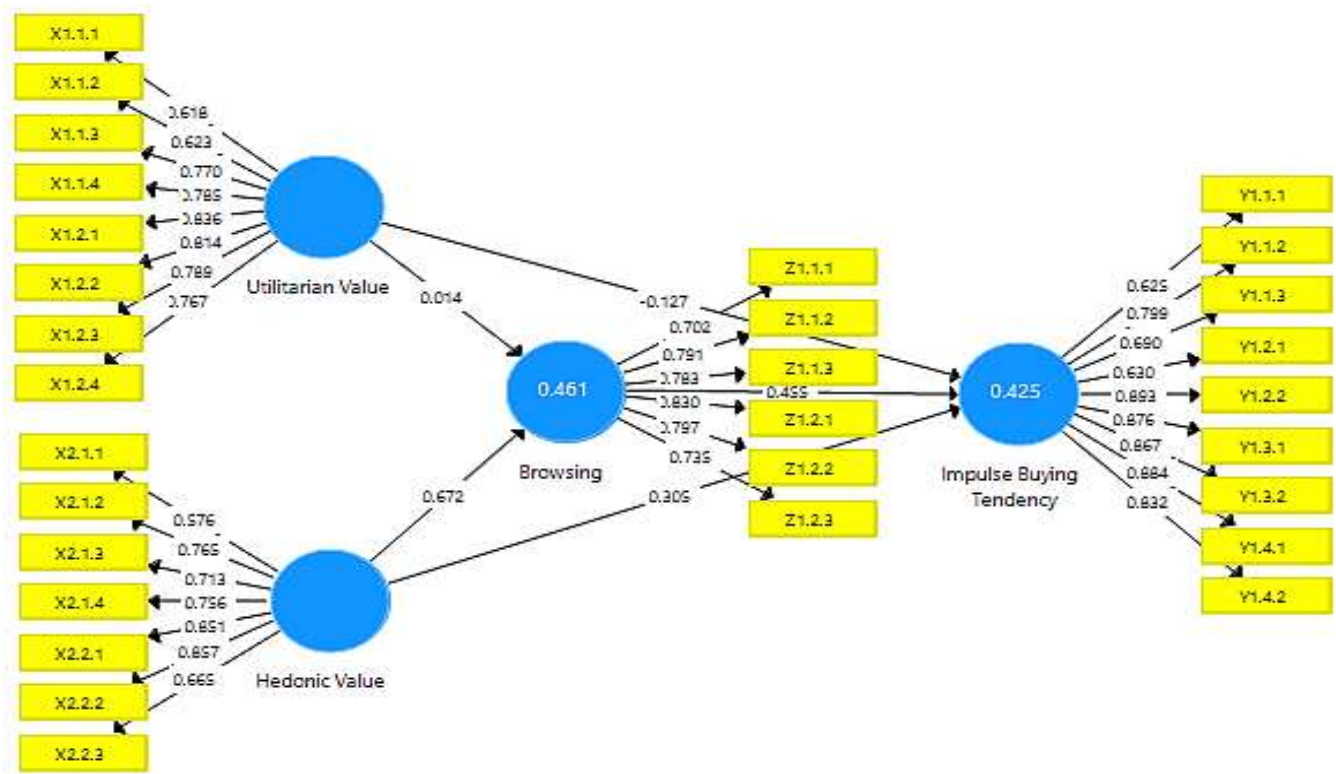

Sumber: Output SmartPLS 3.3 (data diolah)

Gambar 3. UJI MEASUREMENT MODEL

\section{Composite Reliability}

Composite Realibity (CR) dapat dikatakan reliabel apabila nilainya melebihi standar yang telah ditetapkan yaitu 0,70 (Ghozali, 2016). Hasil uji reliabilitas terlihat bahwa semua memiliki nilai melebihi standar yang telah ditetapkan. Hasil lebih detail dapat dilihat di Tabel 2.

Tabel 2.

\section{COMPOSITE RELIABILITY}

\begin{tabular}{lc}
\hline \multicolumn{1}{c}{ Variabel } & Composite Reliability \\
\hline Utilitarian Value & 0,899 \\
Hedonic Value & 0,898 \\
Browsing & 0,938 \\
Impulse Buying Tendency & 0,913 \\
\hline Sumber: Output SmartPLS 3.3 (data diolah)
\end{tabular}

\section{Cronbach's Alpha}

Cronbach's alpha dapat memperkuat hasil uji reliabilitas dari composite reliability sebelumnya, standar minimal dari Croanbach's Alpha (CA) yaitu 0,60 (Siregar, 2017). Hasil uji menunjukkan bahwa semua konstruk telah sesuai dengan standar minimal yang telah ditetapkan yaitu variabel utilitatian value dengan nilai 0,900 ; hedonic value 0,869 ; browsing 0,866 ; dan variabel impulse buying tendency memiliki nilai 0,924 .

\section{R-Square}

Hasil uji dari nilai $R^{2}$ untuk impulse buying tendency adalah 0,425. Nilai tersebut menunjukkan bahwa variabel impulse buying tendency yang dijelaskan oleh utilitarian value, hedonic value dan browsing sebesar $42,5 \%$, sedangkan sisanya dijelaskan oleh variabel lain yang tidak ada di penelitian ini. Nilai $R^{2}$ untuk browsing adalah 0,461. Nilai tersebut menunjukkan bahwa variabel browsing yang dijelakan oleh utilitarian value dan hedonic value sebesar $46,1 \%$, sedangkan sisanya dijelaskan oleh variabel lain yang tidak ada di penelitian ini.

\section{Path Coefficients}

Tabel 3 menunjukkan bahwa pengaruh utilitian value terhadap browsing pada pengguna marketplace Shopee memiliki nilai $t$-statistics 0,179 . Hasil tersebut memiliki nilai yang lebih kecil dari 1,96 namun 
Evi Mardian Ningsih \& Anik Lestari Andjarwati. Peran Consumer Perceived Value dalam Online Review terhadap Impulse Buying Tendency melalui Browsing sebagai Variabel Intervening

memiliki nilai positif. Sehingga tidak ada pengaruh yang siginifikan dari utilitarian value terhadap browsing, maka dengan hasil tersebut tidak perlu untuk melihat koefisien estimate karena setinggi atau serendah apapun utilitarian value tidak berpengaruh pada browsing. Selanjutnya, untuk pengaruh hedonic value terhadap browsing pada pengguna marketplace Shopee memiliki nilai $t$-statistics 10,863. Hasil tersebut memiliki nilai yang lebih besar dari 1,96. Koefisien estimate memiliki nilai 0,672 artinya hedonic value terhadap browsing adalah searah. Jika hedonic value yang dirasakan konsumen semakin tinggi, maka perilaku browsing di marketplace Shopee semakin tinggi.

Tabel 3.

PATH COEFFICIENTS

\begin{tabular}{lcccc}
\hline $\begin{array}{c}\text { Hubungan } \\
\text { antar Variabel }\end{array}$ & $\begin{array}{c}\text { Original } \\
\text { Sample }\end{array}$ & T-Statistics & Keterangan & Hasil \\
\hline$U V \rightarrow B R W$ & 0,014 & 0,179 & $\leq 1,96$ (Tidak Sig.) & Tidak Terbukti \\
$H V \rightarrow B R W$ & 0,672 & 10,863 & $\geq 1,96$ (Sig.) & Terbukti \\
$U V \rightarrow I B T$ & $-0,120$ & 1,383 & $\leq 1,96$ (Tidak Sig.) & Tidak Terbukti \\
$H V \rightarrow I B T$ & 0,611 & 8,915 & $\geq 1,96$ (Sig.) & Terbukti \\
$B R W \rightarrow I B T$ & 0,455 & 6,388 & $\geq 1,96$ (Sig.) & Terbukti \\
\hline
\end{tabular}

Sumber: Output SmartPLS 3.3 (data diolah)

Pengaruh utilitarian value terhadap impulse buying tendency memiliki nilai $t$-statistics 1,383 . Hasil tersebut memiliki nilai yang lebih kecil dari 1,96. Sehingga tidak ada pengaruh signifikan dari utilitarian value terhadap impulse buying tendency. Sedangkan, untuk pengaruh hubungan hedonic value terhadap impulse buying tendency memiliki nilai $t$-statistics 8,915 . Nilai tersebut lebih besar dari 1,96 yang artinya hedonic value memiliki pengaruh yang signifikan terhadap impulse buying tendency. Selanjutnya, pengaruh browsing terhadap impulse buying tendency pada pengguna marketplace Shopee memiliki nilai $t$-statistics 6,388. Hasil tersebut memiliki nilai yang lebih besar dari 1,96. Koefisien estimate memiliki nilai 0,455 yang artinya browsing terhadap impulse buying tendency adalah searah. Jika perilaku browsing konsumen semakin tinggi, maka impulse buying konsumen di marketplace Shopee semakin tinggi.

\section{Indirect Effect}

Nilai $t$-statistics berdasarkan hasil pengujian untuk (indirect effect) utilitarian value terhadap impulse buying tendency 0,170 dan lebih kecil dari 1,96 maka hal ini menunjukkan bahwa utilitarian value tidak berpengaruh pada impulse buying tendency apabila dimediasi oleh browsing. Sedangkan, hasil pengujian (indirect effect) hedonic value terhadap impulse buying tendency memiliki nilai $t$-statistics 6,126 dan menunjukkan bahwa hedonic value memiliki pengaruh pada impulse buying tendency melalui browsing.

\section{Pengaruh Utilitarian Value terhadap Browsing}

Penelitian ini gagal membuktikan $\mathrm{H} 1$ yang artinya tidak ada pengaruh utilitarian value beserta dampaknya pada browsing. Indikasi yang menyebabkan tidak adanya pengaruh dari utilitarian value pada browsing dimungkinkan konsumen hanya melakukan browsing di marketplace Shopee dengan suatu tujuan tertentu. Selain itu, konsumen hanya akan melakukan browsing untuk memenuhi kebutuhan misalnya belanja bulanan. Sebagian besar konsumen melakukan pembelian di marketplace Shopee dengan kurun waktu sebulan sekali. Produk fashion dan kecantikan merupakan jenis produk yang paling banyak dibeli oleh konsumen di marketplace Shopee. Konsumen akan lebih fokus pada produk yang telah direncakan sebelumnya dan hanya memperhatikan hal-hal tertentu seperti kegunaan dan manfaat dari apa yang mereka cari. Sehingga, hal ini memungkinkan tingkat browsing konsumen rendah dan jarang memperhatikan ulasan online dari konsumen lainnya. Hasil penelitian ini tidak sejalan dengan penelitian yang dilakukan oleh Wahab et al. (2018) dan Mikalef et al. (2012), di mana utilitarian value memiliki nilai positif dan signifikan.

\section{Pengaruh Hedonic Value terhadap Browsing}

Hubungan pengaruh hedonic value terhadap browsing terbukti menerima $\mathrm{H} 2$ artinya hedonic value memengaruhi browsing. Responden penelitian menyatakan bahwa mereka akan menjelajahi 
marketplace Shopee ketika merasa senang. Kesenangan dan kenikmatan yang diterima konsumen dari ulasan online akan menghabiskan waktu mereka untuk menjelajahi. Semakin tinggi kesenangan konsumen, semakin baik konsumen akan melakukan browsing di marketplace Shopee. Hasil penelitian juga menunjukkan bahwa smartphone merupakan alat komunikasi yang paling banyak digunakan ketika menjelajahi atau hanya sekedar berkunjung di marketplace Shopee. Selain itu, hal tersebut juga dibuktikan dengan jenis pekerjaan responden yang di dominasi oleh kaum dewasa muda yaitu siswa/mahasiswa. Siswa/mahasiswa merupakan kelompok yang menganggap kesenangan sebagai tujuan hidup dan tidak dapat terlepas dari perilaku hedonisme (Thionita, 2019). Hal ini, tentunya sangat bermanfaat bagi pemasar dan Shopee karena pemasar akan memberikan berbagai macam tawaran baik berupa diskon maupun yang lainnya untuk meningkatkan rasa kesenangan konsumen, sehingga konsumen semakin aktif untuk melakukan browsing dan untuk Shopee akan mengalami peningkatan pengunjung perharinya. Menurut Wahab et al. (2018), konsumen dengan hedonic value dapat melakukan browsing sebelum memutuskan untuk melakukan pembelian. Konsumen akan menikmati proses browsing produk sebagai kesenangan karena kemudahan fasilitas dan stimulus yang ditawarkan pemasar seperti banyaknya pilihan produk dengan model yang selalu mengikuti tren, kemudahan proses pencarian produk, dan penawaran promosi yang dapat mendorong konsumen untuk membeli produk. Penelitian ini mendukung penelitian yang dilakukan oleh Zhang et al. (2018); Pöyry et al. (2013); dan Wahab et al. (2018).

\section{Pengaruh Utilitarian Value terhadap Impulse Buying Tendency}

Utilitarian value tidak dapat memengaruhi impulse buying tendency artinya $\mathrm{H} 3$ gagal terbukti. Nilai kegunaan seperti kualitas produk yang baik dengan harga murah yang disimulasikan oleh e-commerce dapat memicu prilaku impulse buying. Namun, semakin tinggi tingkat impulsif konteks spesifik konsumen, semakin banyak produk yang akan di beli secara impulsif dan begitu pula sebaliknya. Sebagian besar konsumen melakukan pembelian di marketplace Shopee dengan kurun waktu sebulan sekali dan lebih fokus pada karakteristik produk yang telah direncakan sebelumnya misalnya fokus pada satu toko official dan wilayah toko berada. Lokasi toko akan berkaitan dengan lama pengiriman dan biaya pengiriman. Hal ini memungkinkan konsumen hanya mementingkan kegunaan dari apa yang akan dibeli tanpa memperhatikan penawaran-penawaran yang disediakan oleh pemasar dan Shopee. Penelitian ini sejalan dengan penelitian yang dilakukan oleh Wahab et al. (2018) dan Chung et al. (2017) yang di mana utilitarian value seseorang dalam berbelanja tidak memiliki pengaruh langsung terhadap perilaku impulse buying. Konsumen yang lebih rasional dan non-emosional dalam berbelanja akan lebih mempertimbangkan nilai fungsional dari produk yang mereka beli. Hal ini bertentangan dengan perilaku impulse buying yang memiliki ciri pengambilan keputusan dalam waktu yang relatif cepat, spontan, tanpa pikir panjang, dan tanpa mempertimbangkan konsekuensi pembelian produk.

\section{Pengaruh Hedonic Value terhadap Impulse Buying Tendency}

Hasil penelitian mampu membuktikan $\mathrm{H} 4$ yang artinya hedonic value memengaruhi impulse buying tendency. Semakin tinggi tingkat impulsif situasional konsumen misalnya nilai kesenangan, semakin banyak produk yang akan di beli secara impulsif. Selain itu, hedonic value memiliki pengaruh yang lebih kuat dibandingkan dengan utilitarian value terhadap perilaku konsumen untuk membeli secara impulsif melalui media elektronik. Hal ini menunjukkan bahwa konsumen akan lebih senang ketika terdapat penawaran yang menarik di marketplace Shopee dan tanpa sadar memasukkan produkproduk tersebut ke dalam keranjang. Bahkan, terdapat konsumen yang langsung men-cheklist belanjaan tersebut karena takut produk tersebut akan habis. Selain itu, konsumen dengan hedonic value tinggi akan berbelanja secara emosional tanpa banyak pertimbangan dan selalu berusaha untuk segera memenuhi keinginan untuk memuaskan dirinya sehingga mereka lebih cepat mengambil keputusan pembelian (impulse buying) (Park et al., 2012).

Responden penelitian ini didominasi oleh kaum dewasa muda yang melakukan pembelian untuk mendapatkan kesenangan dan kepuasan. Ketika konsumen saling berlomba untuk mendapatkan produk, hal ini justru sangat menguntungkan bagi pemasar khususnya di marketplace Shopee karena untuk marketplace Shopee akan mengalami peningkatan pengunjung. Karakter yang berbeda 
Evi Mardian Ningsih \& Anik Lestari Andjarwati. Peran Consumer Perceived Value dalam Online Review terhadap Impulse Buying Tendency melalui Browsing sebagai Variabel Intervening

ditemukan pada konsumen dengan usia di atas 30 tahun yang telah mengetahui produk yang diinginkan meski belum tahu merek apa yang akan dipilih. Hal ini membuktikan bahwa semakin berumur konsumen, semakin bijak mereka dalam berbelanja. Konsumen tersebut lebih mengetahui pilihannya dan tidak impulsif dalam berbelanja (Fauzia, 2019). Penelitian ini mendukung penelitian yang dilakukan oleh Floh \& Madlberger (2013); Lim et al. (2017); Gultekin \& Ozer (2012); Wahab et al. (2018); dan Wang (2017).

\section{Pengaruh Browsing terhadap Impulse Buying Tendency}

Penelitian ini mampu membuktikan hubungan antara browsing dan impulse buying tendency yang artinya H5 terbukti. Browsing merupakan perilaku non-pembelian dan dianggap sebagai aktivitas untuk bersenang-senang dan mengisi waktu menunggu (Yi \& Jai, 2020). Browsing yang dilakukan konsumen tentunya sangat memengaruhi tingat pembelian secara impulsif, sesuai teori yang dijelaskan bahwa konsumen akan menjelajahi ketika mereka merasa senang atau berada pada emosional yang menyenangkan. Sehingga semakin senang konsumen, semakin aktif dalam melakukan browsing dan akhirnya melakukan pembelian. Selain itu, kaum dewasa muda yang menjadi responden penelitian ini didominasi oleh perempuan. Hal ini membuktikan bahwa perilaku perempuan yang sekedar hanya melakukan browsing pada marketplace Shopee nyatanya dapat mengarahkan mereka pada pembelian. Apalagi, ketika pemasar memberikan penawaran terbaik dan Shopee memberikan pelayanan yang terbaik berupa hiburan. Pengaruh browsing terhadap impulse buying tendency dalam penelitian ini mendukung penelitian Park et al. (2012); Floh \& Madlberger (2013); Gultekin \& Ozer (2012); dan Wahab et al, (2018).

\section{Pengaruh Utilitarian Value dan Hedonic Value terhadap Impulse Buying Tendency melalui Browsing}

Berdasarkan penjelasan sebelumnya terkait hasil dari pengujian hipotesis menunjukkan bahwa H6 ditolak atau penelitian ini gagal membuktikan hubungan antara utilitarian value terhadap impulse buying tendency melalui browsing pada pengguna marketplace Shopee. Hal ini terjadi karena konsumen dengan utilitarian value tinggi akan lebih rasional dan non-emosional dalam berbelanja dan akan mempertimbangkan nilai fungsional dari produk yang dibelinya. Dengan demikian karena responden penelitian ini memiliki utilitarian value yang rendah, sebelum melakukan pembelian produk, responden tidak akan terlalu banyak untuk melakukan proses eksplorasi produk. Menurut Chung et al. (2017), konsumen dengan utilitarian value yang lemah tidak akan banyak melakukan browsing sebagai langkah awal untuk mencari informasi tentang produk tersebut. Konsumen akan lebih mengetahui pilihannya dan tidak impulsif dalam berbelanja (Fauzia, 2019).

Selain itu, utilitarian value tidak berpengaruh terhadap browsing maupun impulse buying, sehingga dapat diartikan bahwa konsumen lebih mengutamakan dan menitik-beratkan nilai kesenangan yang diterima setelah membaca penilaian dari konsumen lain dan ikut merasakan perasaan konsumen lain yang telah membeli produk tersebut dan tentunya penelitian ini terbukti menerima $\mathrm{H} 7$ yang di mana hedonic value atau nilai kesenangan mampu memengaruhi impulse buying tendency melalui browsing pada pengguna marketplace Shopee. Konsumen yang merasakan hedonic value akan mengeksplorasi atau mencari informasi produk yang lebih lama dan menikmati proses browsing sebagai kesenangan dalam memenuhi hasrat konsumen yang selanjutnya dapat meningkatkan impulse buying (Erkip, 2005). Hal ini mendukung penelitian oleh Chung et al. (2017), Ha \& Jang, (2010), Chen et al. (2019); Gultekin \& Ozer (2012), Erkip, (2005) dan Wahab et al. (2018).

\section{KESIMPULAN}

Utilitarian value gagal membuktikan hubungannya dengan browsing, dan impulse buying tendency. Sedangkan, hedonic value terbukti memengaruhi browsing dan impulse buying tendency. Kemudian, browsing tidak dapat memediasi hubungan antara utilitarian value dan impulse buying tendency. Browsing terbukti mampu memengaruhi impulse buying tendency dan dapat memediasi hubungan antara hedonic value dan impulse buying tendency. Nilai yang dirasakan konsumen dapat memberikan apa yang diinginkan dan dipercaya konsumen selama berbelanja atau menikmati layanan. Hal tersebut membuktikan bahwa hedonic value memiliki pengaruh yang lebih kuat dibandingkan dengan 
utilitarian value terhadap perilaku konsumen untuk membeli secara impulsif melalui elektronik.

Penelitian ini memiliki keterbatasan yaitu penelitian ini hanya melibatkan marketplace Shopee, sehingga kemungkinan tidak dapat digeneralisir untuk semua jenis marketplace dan untuk penelitian selanjutnya dapat melibatkan atau membandingkan marketplace lain seperti Tokopedia, Lazada, Blibli ataupun marketplace lainnya. Penelitian ini tidak banyak melibatkan variabel lain mungkin penelitian selanjutnya dapat melibatkan variabel lain seperti expressive value, sacrifice value, web quality, dan purchase intention.

\section{DAFTAR PUSTAKA}

Adetunji, R. R., Sabrina, M. R., \& Sobhi, I. M. (2017). User-Generated Contents in Facebook, Functional and Hedonic Brand Image and Purchase Intention. SHS Web of Conferences, 33, 00084. https://doi.org/10.1051/shsconf/20173300084.

Astyawan, P. R. (2020). Aktivitas Jadi Serba Online saat Pandemi Covid-19, Siapkah Pemerintah Memfasilitasi? Retrieved November 30, 2020, from Nasional.Okezone.Com website: https://nasional.okezone.com/read/2020/06/19/337/2233143/aktivitas-jadi-serba-online-saatpandemi-covid-19-siapkah-pemerintah-memfasilitasi.

Bayley, G., \& Nancarrow, C. (1998). Impulse purchasing: A qualitative exploration of the phenomenon. Qualitative Market Research: An International Journal, 1(2), 99-114. https://doi.org/10.1108/13522759810214271.

Beatty, S. E., \& Elizabeth Ferrell, M. (1998). Impulse buying: Modeling its precursors. Journal of Retailing, 74(2), 161-167. https://doi.org/10.1016/s0022-4359(98)90009-4.

Blazevic, V., Hammedi, W., Garnefeld, I., Rust, R. T., Keiningham, T., Andreassen, T. W., ... Carl, W. (2013). Beyond traditional word-of-mouth: An expanded model of customer-driven influence. Journal of Service Management, 24(3), 294-313. https://doi.org/10.1108/09564231311327003.

Bloch, P. H., Ridgway, N. M., \& Sherrell, D. L. (1989). Extending the concept of shopping: An investigation of browsing activity. Journal of the Academy of Marketing Science, 17(1), 13-21. https://doi.org/10.1007/BF02726349.

Chen, Y., Lu, Y., Gupta, S., \& Pan, Z. (2019). Understanding "window" shopping and browsing experience on social shopping website: An empirical investigation. Information Technology and People, 33(4), 1124-1148. https://doi.org/10.1108/ITP-12-2017-0424.

Chung, C., \& Austria, K. P. (2012). Attitudes Toward Product Messages on Social Media. International Journal of E-Services and Mobile Applications, 4(4), 1-14. https://doi.org/10.4018/jesma.2012100101.

Chung, N., Song, H. G., \& Lee, H. (2017a). Consumers' impulsive buying behavior of restaurant products in social commerce. International Journal of Contemporary Hospitality Management, 29(2), 709-731. https://doi.org/10.1108/IJCHM-10-2015-0608.

Chung, N., Song, H. G., \& Lee, H. (2017b). Perceived values, satisfaction, and behavioral intentions: The role of familiarity in Korean restaurants. International Journal of Hospitality Management, 29(2), 709-731. https://doi.org/http://dx.doi.org/10.1016/j.ijhm.2009.03.009.

Deny, S. (2019). Deretan E-Commerce Favorit Orang Indonesia , Apa Saja? Retrieved November 30, 2020, from Liputan6.Com website: https://www.liputan6.com/bisnis/read/3963992/deretan-ecommerce-favorit-orang-indonesia-apa-saja. 
Evi Mardian Ningsih \& Anik Lestari Andjarwati. Peran Consumer Perceived Value dalam Online Review terhadap Impulse Buying Tendency melalui Browsing sebagai Variabel Intervening

Ellis, D. (1993). Modeling The Information-Seeking Patterns Of Academic Reseachers: A Graounded Theory Approach. Chicago Journals, 63(4), 469-486. Retrieved from http://www.jstor.org/stable/4308867.

Erkip, F. (2005). The rise of the shopping mall in Turkey: The use and appeal of a mall in Ankara. Cities, 22(2), 89-108. https://doi.org/10.1016/j.cities.2004.10.001.

Fauzia, M. (2019). Perempuan Indonesia Belanja Online: Impulsif hingga Tergiur Gratis Ongkir. Retrieved June 19, 2021, from Kompas.Com website: https://money.kompas.com/read/2019/04/04/123029126/perempuan-indonesia-belanja-onlineimpulsif-hingga-tergiur-gratis-ongkir?page=all.

Floh, A., \& Madlberger, M. (2013). The role of atmospheric cues in online impulse-buying behavior. Electronic Commerce Research and Applications, 12(6), 425-439. https://doi.org/10.1016/j.elerap.2013.06.001.

Ghozali, I. (2016). Aplikasi Analisis Multivariete Dengan Program IBM SPSS 23 (8th ed.). Semarang: Badan Penerbit Universitas Diponegoro.

Gultekin, B., \& Ozer, L. (2012). The Influence of Hedonic Motives and Browsing On Impulse Buying. Journal of Economics and Behavioral Studies, 4(3), 180-189. https://doi.org/10.22610/jebs.v4i3.315.

Ha, J., \& Jang, S. C. (2010). Perceived values, satisfaction, and behavioral intentions: The role of familiarity in Korean restaurants. International Journal of Hospitality Management, 29(1), 213. https://doi.org/10.1016/j.ijhm.2009.03.009.

Hazari, S., Bergiel, B. J., \& Sethna, B. N. (2017). Hedonic and utilitarian use of user-generated content on online shopping websites. Journal of Marketing Communications, 23(6), 572-591. https://doi.org/10.1080/13527266.2016.1143383.

Holbrook, M.B., \& Hirschman, E. C. (1982). The experiental aspect of consumption: Consumption fantasies, feelings and fun. Journal of Consumer Research, 9(2), 132-140.

Iprice, I. (2019). Daftar 50 Website \& Aplikasi E-Commerce di Indonesia 2018. Retrieved November 30, 2020, from Peta E-Commerce Indonesia website: https://iprice.co.id/insights/mapofecommerce/.

Kim, H. S. (2006). Using Hedonic and Utilitarian Shopping Motivations to Profile Inner City Consumers. Journal of Shopping Center Research, 13(1), 57-79.

Kim, S., \& Eastin, M. S. (2011). Hedonic tendencies and the online consumer: An investigation of the online shopping process. Journal of Internet Commerce, 10(1), 68-90. https://doi.org/10.1080/15332861.2011.558458.

Kominfo. (2020). Kementerian Komunikasi dan Informatika. Retrieved November 30, 2020, from https://kominfo.go.id/index.php/content/detail/3415/Kominfo+\%3A+Pengguna+Intern et+di+Indonesia+63+Juta+Orang/0/berita_satker.

Lee, C.-H., \& Wu, J. J. (2017). Consumer online flow experience. Industrial Management \& Data Systems, 117(10), 2452-2467. https://doi.org/10.1108/IMDS-11-2016-0500.

Lee, J. A., \& Kacen, J. J. (2002). The Influence of Culture on Consumer Impulsive Buying Behavior. Journal of Consumer Psychology, 12(2), 163-176. https://doi.org/10.4324/9781315865294-6. 
Lim, S. H., Lee, S., \& Kim, D. J. (2017). Is Online Consumers' Impulsive Buying Beneficial for ECommerce Companies? An Empirical Investigation of Online Consumers' Past Impulsive Buying Behaviors. Information Systems Management, 34(1), 85-100. https://doi.org/10.1080/10580530.2017.1254458.

Malhotra, N. (2009). Riset Pemasaran Pendekatan Terapan. Jakarta: PT. Indeks.

Mikalef, P., Giannakos, M., \& Pateli, A. (2012). Shopping and word-of-mouth intentions on social media. Journal of Theoretical and Applied Electronic Commerce Research, 8(1), 17-34. https://doi.org/10.4067/S0718-18762013000100003.

Moe, W. W. (2003). Buying, Searching, or Browsing: Differentiating Between Online Shoppers Using In-Store Navigational Clickstream. Journal of Consumer Psychology, 13(1-2), 29-39. https://doi.org/https://doi.org/10.1207/S15327663JCP13-1\&2_03.

Overby, J. W., \& Lee, E. J. (2006). The effects of utilitarian and hedonic online shopping value on consumer preference and intentions. Journal of Business Research, 59(10-11), 1160-1166. https://doi.org/10.1016/j.jbusres.2006.03.008.

Parboteeah, D. V., Valacich, J. S., \& Wells, J. D. (2009). The Influence of Website Characteristics on a Consumer's Urge to Buy Impulsively. Information Systems Research, 20(1), 60-78. https://doi.org/10.1287/isre.1070.0157.

Park, E. J., Kim, E. Y., Funches, V. M., \& Foxx, W. (2012). Apparel product attributes, web browsing, and e-impulse buying on shopping websites. Journal of Business Research, 65(11), 1583-1589. https://doi.org/10.1016/j.jbusres.2011.02.043.

Piron, F. (1991). Defining Impulse Purchasing. Advances in Consumer Research, 18, 509-514.

Pöyry, E., Parvinen, P., \& Malmivaara, T. (2013). Can we get from liking to buying? Behavioral differences in hedonic and utilitarian Facebook usage. Electronic Commerce Research and Applications, 12(4), 224-235. https://doi.org/10.1016/j.elerap.2013.01.003.

Rook, D. W. (1987). The Buying Impulse. Journal of Consumer Research, 14(2), 189. https://doi.org/10.1086/209105.

Santia, T. (2020). Aktivitas belanja online naik 28,9 persen saat pandemi covid-19. Retrieved November 30, 2020, from Liputan6.Com website: https://www.liputan6.com/bisnis/read/4274623/aktivitas-belanja-online-naik-289-persen-saatpandemi-corona.

Sharma, P., Sivakumaran, B., \& Marshall, R. (2010). Impulse buying and variety seeking: A traitcorrelates perspective. Journal of Business Research, 63(3), 276-283. https://doi.org/10.1016/j.jbusres.2009.03.013.

Singh, H., \& Chakrabarti, S. (2020). Defining the relationship between consumers and retailers through user-generated content: insights from the research literature. International Journal of Retail and Distribution Management. https://doi.org/10.1108/IJRDM-03-2020-0080.

Siregar, S. (2017). Statistik Parametrik untuk Penelitian Kuantitatif: dilengkapi dengan perhitungan manual dan aplikasi SPSS versi 17 (1st ed.). Jakarta: Bumi Aksara.

Smith, J. B., \& Colgate, M. (2007). Customer value creation: A practical framework. Journal of Marketing Theory and Practice, 15(1), 7-23. https://doi.org/10.2753/MTP1069-6679150101. 
Evi Mardian Ningsih \& Anik Lestari Andjarwati. Peran Consumer Perceived Value dalam Online Review terhadap Impulse Buying Tendency melalui Browsing sebagai Variabel Intervening

Thionita, V. (2019). Bahaya Perilaku Konsumerisme, Materialisme, Hedonisme Pada Kehidupan Seseorang. Retrieved June 21, 2021, from Finansialku.com website: https://www.finansialku.com/konsumerisme-materialisme-hedonisme/.

Tokopedia.com. (2020). 9 Tips Belanja Online agar Aman dan Terhindar dari Penipuan. Retrieved April 22, 2021, from https://www.tokopedia.com/blog/tips-belanja-online-tek/.

Uli. (2020). Transaksi e-Commerce Naik Nyaris Dua Kali Lipat saat Pandemi. Retrieved November 30, 2020, from Cnn Indonesia website: https://www.cnnindonesia.com/ekonomi/20201021193353-92-561232/transaksi-e-commercenaik-nyaris-dua-kali-lipat-saat-pandemi.

Verhagen, T., \& Van Dolen, W. (2011). The influence of online store beliefs on consumer online impulse buying: A model and empirical application. Information and Management, 48(8), 320327. https://doi.org/10.1016/j.im.2011.08.001.

Wahab, Z., Shihab, M. S., Hanafi, A., \& Mavilinda, H. F. (2018). The influence of online shopping motivation and product browsing toward impulsive buying of fashion products on a social commerce. Jurnal Manajemen Motivasi, 14(1), 32. https://doi.org/10.29406/jmm.v14i1.1030.

Wang, E. S.-T. (2017). Creating Utilitarian and Hedonic Value from Website Quality and Online Retail Performance. Journal of Electronic Commerce in Organizations, 15(3), 1-13. https://doi.org/10.4018/JECO.2017070101.

Wang, E. S. T. (2010). Internet usage purposes and gender differences in the effects of perceived utilitarian and hedonic value. Cyberpsychology, Behavior, and Social Networking, 13(2), 179183. https://doi.org/10.1089/cyber.2009.0200.

WeAreSocial. (2012). We Are Social's Monday Mashup \#142. Retrieved April 22, 2021, from Http://Wearesocial.Net website: http://wearesocial.net/blog/2012/11/socials-monday-mashup$142 /$.

Wilson, T. (1999). Models in information behv. Journal of Documentation, 55(3), 266-268.

Woodruff, R. B. (1997). Customer value the next source for competitive advantage. Journal of Academy of Marketing Science, 25(2), 139-153.

Xia, L. (2010). Qualitative Market Research: An International Journal Article information: An Examination of Consumer Browsing Behaviors, 13(2), 154-173. https://doi.org/10.1108/13522751011032593.

Yi, S., \& Jai, T. (2020). Impacts of consumers' beliefs, desires and emotions on their impulse buying behavior: application of an integrated model of belief-desire theory of emotion. Journal of Hospitality Marketing and Management, 29(6), 662-681. https://doi.org/10.1080/19368623.2020.1692267.

Zhang, K. Z. K., Xu, H., Zhao, S., \& Yu, Y. (2018). Online reviews and impulse buying behavior: the role of browsing and impulsiveness. Internet Research, 28(3), 522-543. https://doi.org/10.1108/IntR-12-2016-0377.

Zhang, K. Z. K., Zhao, S. J., Cheung, C. M. K., \& Lee, M. K. O. (2014). Examining the influence of online reviews on consumers' decision-making: A heuristic-systematic model. Decision Support Systems, 67, 78-89. https://doi.org/10.1016/j.dss.2014.08.005. 